\title{
Perception of Mothers on Adequate Nutrition
}

\author{
Darshini Valoo, ${ }^{1}$ Aly Diana, ${ }^{2}$ Sharon Gondodiputro ${ }^{3}$ \\ ${ }^{1}$ Faculty of Medicine, Universitas Padjadjaran, ${ }^{2}$ Departmen of Public Health Faculty of Medicine \\ Universitas Padjadjaran, ${ }^{3}$ Department of Public Health Faculty of Medicine Universitas \\ Padjadjaran
}

\begin{abstract}
Background: Malnutrition in children less than 5 years old persists around the world. In West Java and one of the districts of West Java (Sumedang), the prevalence of malnutrition is about 18.5\% and $15.8 \%$ respectively. Numerous factors can lead to child malnutrition. Difficulties in availability, accessibility, acceptability and quality of food can be contributing factors. A good perception of mother on adequate nutrition can improve children's nutritional status. This study was conducted to study the perception of mothers with children 2 to 5 years old on adequate nutrition.

Methods: Most of the respondents had good perception on the aspect of adequate nutrition. Results showed perception on availability was $83.8 \%$, physical accessibility was $97.1 \%$, economical accessibility was $98.6 \%$, information accessibility was $84.8 \%$ and acceptability was $81.0 \%$. However, perception of respondents on good quality nutrition for the main meal and additional food was still poor. Moreover, there are taboos for eating shrimp and watermelon. Additionally, children were given snacks in large amount.

Results: There was a strong correlation between mid-upper arm muscle area/size and muscular strength (correlation cooefficient 0.746). Moreover, the higher the Body Mass Index, the stronger the muscle strength was to some point. If the BMI was more than $25 \mathrm{~kg} / \mathrm{m}^{2}$, this findings did not occurred.

Conclusions: This study reveals that the perception of mothers on good quality food is poor regardless the good results on availibility, accesibility and acceptability. [AMJ.2017;4(1):87-93]
\end{abstract}

Keywords: Acceptability, accessibility, availability, nutrition

\section{Introduction}

The deaths of children under 5 years old due to malnutrition still persist. ${ }^{1}$ Malnutrition is a life-threatening condition that needs special attention. In Indonesia, the prevalence rate of malnutrition in children under five years old is $22.7 \%$ and in West Java about $18.5 \%$. Sumedang, a district in West Java where the study was carried out, the percentage of malnutrition is $15.8 \%{ }^{2}$

In another way, adequate nutrition is very crucial for children in particular for the under five years old children for early brain development. ${ }^{3}$ Inadequate nutrition can affect the overall health of a child including the intellectual development as well as the rate of motor development and rate of physical growth. Isabelle ${ }^{4}$ highlighted that undernutrition children in Indonesia are the major contributing factor that affects the growth and development. ${ }^{4}$

An inadequate nutrition may be a result of less food stock availability and accessibility of nutrition due to the economic status of the family. Based on a study, most of the children from low income families in developing country are the victim of malnutrition. ${ }^{5}$

Besides, lack of knowledge of rights on nutrition due to improper information delivery to mothers can be another factor lead to malnutrition. ${ }^{6}$ Education is one of the most important resources that enable women to provide appropriate care for their children, which is a critical determinant of children's growth and development. ${ }^{6}$

Moreover, the available food source should be acceptable in the cultural traditions of the family and be of high quality so that the consumer can get good and satisfying food.? 
The responsibility of children in malnutrition condition usually goes to the family, especially to the caregiver and to the community. The objectives of this study was to identify the perception of mothers with children 2 to 5 years old on adequate nutrition.

\section{Methods}

This study was carried out in Jatinangor, SumedangWest Java from October to November 2013. The rapid survey was performed on mothers with children 2 to 5 years old in 30 Posyandu around Jatinangor. Cluster sampling was used to select 30 Posyandu from 3 villages. The mothers who were willing to participate in the study were selected as the research subjects. In every Posyandu, seven respondents were chosen which summed up to 210 respondents in total from 30 Posyandu.

The respondents were informed consent on the procedure of the study. The questionnaire on rights to optimal nutrition consisted of four main criteria; availability, accessibility, acceptability and quality. ${ }^{8}$ Components of availibility were the overall availibility of source of food, source of carbohydrate, protein, fat, vitamins and minerals. Components of accesibility were the physical/geographical, economical (affordability) and information availibility. Moreover, acceptability was defined as there were taboos or no taboos on certain food. Quality was determined by some components, namely the source of children's meal, frequency of main and additional meals per day, frequency of snacks per day, and calorie consumption per day according to Angka Kecakupan Gizi orang Indonesia. The answering of the questionnaire was carried out by interview method.

The data collected was analyzed using computer software. The results were performed using tables.

Table 1 Characteristics of Respondents

\begin{tabular}{lc}
\hline \multicolumn{1}{c}{ Variable } & $\mathbf{n}$ (\%) \\
\hline Mother's education status & $43(20.5)$ \\
Elementary & $82(39.0)$ \\
Junior High School & $78(37.1)$ \\
Senior High School & $2(1.0)$ \\
Diploma & $4(1.9)$ \\
Bachelor & $1(0.5)$ \\
Master & \\
Father's occupation & $1(0.5)$ \\
Government worker & $95(45.2)$ \\
Labor & $2(1.0)$ \\
Security & $2(1.0)$ \\
Driver & $40(19.0)$ \\
Private & $65(31.0)$ \\
Business & $5(2.4)$ \\
Civil servant & \\
Mother's occupation & $6(2.9)$ \\
Labor & $3(1.4)$ \\
Civil servant & $18(8.6)$ \\
Private & $12(5.7)$ \\
Business & $171(81.4)$ \\
Housewife &
\end{tabular}


Table 2 Availability and Types of Food

\begin{tabular}{lc}
\hline \multicolumn{1}{c}{ Variable } & n (\%) \\
\hline Availability of all kinds of food & $176(83.8)$ \\
Yes & $34(16.2)$ \\
No & \\
Types of food source available & \\
Carbohydrate & $120(57.1)$ \\
$\quad$ Rice & $67(31.9)$ \\
Noodle & $55(26.2)$ \\
Bread & $89(42.4)$ \\
Potato & \\
Protein & $120(57.1)$ \\
Chicken & $56(26.7)$ \\
Beef & $35(16.7)$ \\
Fish & $135(64.3)$ \\
Egg & $130(61.9)$ \\
Tofu & $156(74.3)$ \\
Tempe & $70(33.3)$ \\
Milk & \\
Fat & $113(53.8)$ \\
Oil & $89(42.4)$ \\
Sausage & $34(16.2)$ \\
Cheese & \\
Vitamins and mineral & $108(51.4)$ \\
Vegetables & $87(41.4)$ \\
Fruits &
\end{tabular}

\section{Results}

The subjects were apparently healthy men The minimum level of education of the subjects was elementary school and maximum level was of Masters. The occupational background showed various jobs listed such as labor, civil servant, private, and business; in addition the majority of the respondents were housewives (Table 1).

There were all kinds of nutrient from carbohydrate, protein, fat, vitamin and minerals. There were varieties of food from every food class as mentioned in Table 2 .

Most of the sources of carbohydrate were from rice and potato. In terms of protein, most of its sources were tempe, tofu, eggs and chicken. The source of fat was from oil and most of the source of vitamins and minerals was from vegetables.

Furthermore, one of the components of adequate nutrition according to the right to health was accesibility of the source of food, which consisted of physical/geographical, economical and information accesibility. This study discovered that most of the mothers did not have any difficulties to access the source of food to fulfill their children's nutrition, except for buying beef (Table 3).

In terms of nutrition information, most of the place where mothers could gain its information was Posyandu, followed by Puskesmas.

Regarding perception of taboo on food, there were 7 respondents who answered there were special taboos like taboos on consuming 
Table 3 Accessibility of Food

\begin{tabular}{lc}
\hline \multicolumn{1}{c}{ Variables } & $\mathbf{n}(\mathbf{\%})$ \\
\hline Perception on physical/geographical accessibility & $204(97.1)$ \\
$\quad$ Yes & $6(2.9)$ \\
$\quad$ No & \\
Distance of food source from house & $183(87.1)$ \\
$\quad \leq 1 \mathrm{~km}$ & $27(12.9)$ \\
$\quad>1 \mathrm{~km}$ & \\
Transportation to reach food source & $146(69.5)$ \\
$\quad$ Walk & $43(20.5)$ \\
$\quad$ Vehicles & $21(10.0)$ \\
$\quad$ Both (walk and vehicle) & \\
Perception on economical accessibility & $207(98.6)$ \\
$\quad$ Yes & $3(1.4)$ \\
No & \\
Food that cannot be afforded & $170(81.0)$ \\
Beef & $21(10.0)$ \\
Chicken & $59(75.7)$ \\
Milk & \\
Information accessibility & $178(84.8)$ \\
Yes & $32(15.2)$ \\
No & \\
Types of information & $103(57.9)$ \\
Nutrition & $75(42.1)$ \\
Health & \\
Pource of information & $81(47.2)$ \\
Midwife & $19(10.7)$ \\
Puskesmas & $29(16.3)$ \\
Internet & $3(1.7)$ \\
\hline
\end{tabular}

watermelon (6 respondents) and shrimp (1 respondent) (Table 4). However, another 33 respondents had perceptions that there were taboos on food such as spicy food, chocolate, cold water and sweet. It could be said that the result was contradictory since it was only a belief by their family and it was not culturally inherited.

The food given to children from 2 to 5 years old were poor in quality (Table 5). This was because 175 respondents out of 210 respondents gave snacks to their children, and the frequency of two times and more of snacks per day was about $83.2 \%$ which was quite high. Moreover, after the calculation of calorie consumption per day according to the Angka Kecakupan Gizi orang Indonesia , almost all of the children had not have the standard calorie intake as it should be according to Indonesian standard.

\section{Discussion}

Based on the study conducted in 3 villages in 
Table 4 Acceptability of Food

\begin{tabular}{|c|c|}
\hline Variable & n (\%) \\
\hline \multicolumn{2}{|l|}{ Food taboo } \\
\hline Yes & $40(19.0)$ \\
\hline No & $170(81.0)$ \\
\hline \multicolumn{2}{|l|}{ Types of food taboo } \\
\hline Shrimp & $1(14.3)$ \\
\hline Watermelon & $6(85.7)$ \\
\hline
\end{tabular}

Jatinangor, Sumedang the result showed that mothers were having a good perception on availability, physical accessibility, information accessibility and acceptability of food for their children.
Availability is sufficient quantity of goods or services. Food is considered as available when there is an existence of all classes of food such as carbohydrate, protein, fat, vitamin and mineral. In this study, the type

\section{Table 5 Quality of Food}

\begin{tabular}{lc}
\hline \multicolumn{1}{c}{ Variable } & $\mathbf{n}(\mathbf{\%})$ \\
\hline Source of meal & \\
Cooked by mothers & $201(95.7)$ \\
Food stall/Warung & $9(4.3)$ \\
Frequency of main meal per day & \\
Once & $1(0.5)$ \\
Twice & $54(25.7)$ \\
Three times & $155(73.8)$ \\
Frequency of additional food per day & \\
Once & $70(35.7)$ \\
Twice & $92(46.9)$ \\
Three times & $42(21.4)$ \\
Four times & $3(1.5)$ \\
Five times & $3(1.5)$ \\
Frequency of snack per day & \\
Once & $26(14.5)$ \\
Twice & $62(34.6)$ \\
Three times & $58(32.4)$ \\
Four times & $7(3.9)$ \\
Five times & $16(8.9)$ \\
Six times & $6(3.4)$ \\
Calorie consumption per day (main meal and additional food according to & \\
the age and average value from Angka Kecakupan Gizi orang Indonesia & \\
Poor & \\
Normal & $108(94.3)$ \\
\hline
\end{tabular}


of food in Indonesia was listed according to the classes and the percentage of availability was calculated. Results showed there was availability of food source since at least one kind of food was available from each class of food. About $83.8 \%$ of respondents were having a good perception on availability.

Accessibility can be defined as the ability to reach or all kinds of services and products. ${ }^{8}$ The second variable studied was perception on accessibility of food source. The distance of food source from the house of the respondent ranged between less than or equal to $1 \mathrm{~km}$ and more than $1 \mathrm{~km}$. The result obtained was $87.1 \%$ of respondents were having food source less than or $1 \mathrm{~km}$ away from their house, and only $12.9 \%$ was more than $1 \mathrm{~km} .^{2}$ Accessible distance according to Riset Kesehatan Dasar (RISKESDAS) is less than or equal to one $\mathrm{km}$. Perception of respondents on physical accessibility could be concluded as good since approximately $97.1 \%$ of respondents stated that according to their understanding it was easy to access the food source. ${ }^{2}$

Economic accessibility is a condition where respondents are able to purchase food stuff from all classes of food even though there are certain food such as beef, chicken or fruits which they cannot often purchase since the price is beyond their affordability. The socioeconomic status of the family does affect the nutritional status of the children. ${ }^{10}$ In general, the respondents had a good perception on economic accessibility since approximately $98.6 \%$ of respondents stated that they could afford to buy the majority of the food.

Information accessibility is achieved when respondents have or get knowledge on adequate nutrition for their children. Good quality food contains nutritious food which is equivalent to the need of the person according to the body weight or an average value as available in Angka kecakupan gizi 2004 bagi orang Indonesia. For children from 2 to 5 years old the average amount of calorie needed is 1000 to $1550 \mathrm{kcal}$ per day. Approximately $84.8 \%$ respondents got information for nutrition and only $15.2 \%$ did not get any information for adequate nutrition. Lack in accessibility to information on adequate nutrition can be a factor for undernourishment or over nourishment in children.

In addition, for acceptability of food $81.0 \%$ had the perception that there was no taboo and only $19.0 \%$ had taboo. Approximately 7 respondents stated that there are taboo to watermelon and shrimp. Based on previous studies, there is existence of taboo on pregnant mothers and there is no information on food taboo for children. ${ }^{11}$

Good quality of food composed of an adequate and a well-balanced diet containing the needed nutrients in the correct amount and number of serving according to the age. Furthermore, the frequency of main meals suggested to be given to children 2 to 5 years old is 3 times daily and additional food twice daily. In this research the frequency of 3 times of main meal was $73.8 \%$ and for additional food with frequency of 2 until 5 times was $66.7 \%$. Another aspect studied was the consumption of snacks among children 2 to 5 years old. From the total of 210 respondents, 85.2\% respondents stated that they gave snacks to their children. Even though snack is poor in nutrition but the amount of calorie in it is sufficient for the daily need of the children. This result provided information that even though the calorie from the main meal and additional food were insufficient but snacks could provide and fulfill the daily calorie requirement in these children.

The limitation of this study is the nutritional status of the children was not studied. Only observation and verbal evidence from health care workers in the posyandu were obtained for nutritional status. The researcher did not measure the nutritional status of the children due to restriction of time and the large sample size. Lack of information on nutritional status caused the researcher was unable to correlate the relationship between under-nutrition and aspects of rights to health.

The conclusion of the study from the 4 aspects studied on rights to health for adequate nutrition, the perception of respondents are overall good. The respondents have achieved good perception on availability, physical accessibility, economic accessibility, information accessibility and acceptability of food. However, for good quality of food the respondent's perception is considered poor. This can be due to lack of exposure on the disadvantage of consuming snacks.

A further study is suggested to be conducted to assess the relationship between the nutritional status of children 2 to 5 years old and aspect of rights to adequate nutrition.

\section{References}

1. Grantham-McGregor S, Cheung YB, Cueto S, Glewwe P, Richter L, Strupp B. Developmental potential in the first 5 years for children in developing countries. Lancet. 2007; 369(9555):60-70. 
2. Departemen Kesehatan Republik Indonesia. Laporan nasional riset kesehatan dasar (Riskesdas) 2007. Jakarta: Departemen Kesehatan Republik Indonesia; 2008.

3. Rosales FJ, Reznick JS, Zeisel SH. Understanding the role of nutrition in the brain \& behavioral development of toddlers and preschool children: identifying and overcoming methodological barriers. Nutr Neurosci. 2009; 12(5):190-202.

4. Isabelle M, Chan P. Seminar on young child nutrition: Improving nutrition and health status of young children in Indonesia. Asia Pac J Clin Nutr. 2011; 20(1):141-7.

5. Van de Poel E, Hosseinpoor AR, Speybroeck $\mathrm{N}$, Van Ourti T, Vega J. Socioeconomic inequality in malnutrition in developing countries. Bull World Health Organ. 2008; 86(4):282-91.

6. Barros FC, Victora CG, Scherpbier RW, Gwatkin D. Health and nutrition of children: equity and social determinants. In: Blas E, Kurup AS, editors. Equity, social determinants and public health programmes. Switzerland: WHO Library
Cataloguing in Publication Data; 2010. p. 49-75

7. Drewnowski A. Concept of a nutritious food: toward a nutrient density score. Am J Clin Nutr. 2005; 82(4):721-32.

8. WHO. 25 Questions and answers on health and human rights: Health and human rights publication series: Geneva: World Health Organization; 2002.

9. Kementerian Kesehatan Republik Indonesia. Peraturan Menteri Kesehatan Nomor 75 Tahun 2013 Tentang Angka Kecukupan Gizi yang Dianjurkan bagi Bangsa Indonesia. Jakarta: Kementerian Kesehatan Republik Indonesia; 2013.

10. Hulshof KF, Brussaard JH, Kruizinga AG, Telman J, Löwik M. Socio-economic status, dietary intake and 10 y trends: The Dutch National Food Consumption Survey. Eur J Clin Nutr. 2003; 57(1):128-37.

11. Hartini TN, Padmawati RS, Lindholm L, Surjono A, Winkvist A. The importance of eating rice: changing food habits among pregnant Indonesian women during the economic crisis. Soc Sci Med. 2005; 61(1):199-210. 